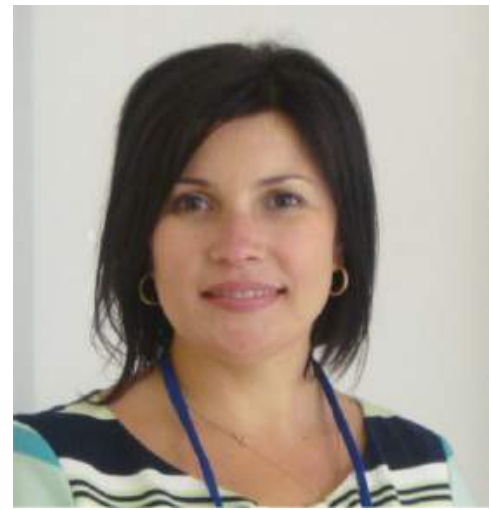

Тетяна Близнюк,

кандидат педагогічних наук, доцент, ДВНЗ «Прикарпатський національний університет імені Василя Стефаника»

(м. Івано-Франківськ)

Tetyana Blyznyuk,

Candidate of Pedagogic Sciences,

Associate Professor

Vasyl Stefanyk Precarpathian national university

(Ivano-Frankivsk)

blyztan@yahoo.com

ID orsid.org/0000-0002-0558-2201

УДК 37. 01. 37. 048.4: 37.

ББК Б-35

\title{
ПЕРСПЕКТИВИ ВИКОРИСТАННЯ ІНФОРМАЦІЙНИХ ТА КОМУНІКАЦІЙНИХ ТЕХНОЛОГІЙ У ГІРСЬКИХ ШКОЛАХ УКРАЇНСЬКИХ КАРПАТ
}

\section{PROSPECTS FOR THE USE OF INFORMATION AND COMMUNICATION TECHNOLOGIES IN MOUNTAIN SCHOOLS OF THE UKRAINIAN CARPATHIANS}

Автор статті висвітлює актуальну для сьогодення проблему використання інформаційних та комунікаційних технологій в освітній галузі, зокрема у гірських школах українських Карпат. Рівень розвитку країни значною мірою визначається рівнем розвитку освіти, яка повинна на сучасному етапі швидко й якісно реагувати на потреби суспільства. Одним із вагомих чинників реформування системи освіти в Україні є її інформатизація. Побудова ефективних систем інформатизації освіти з урахуванням світового досвіду, особливостей і реалій стану вітчизняної освіти - питання, яке заслуговує особливої уваги сучасної наукової теорії і практики. У статті пояснюється необхідність формування цифрової культури і IКТ-компетентності як окремої складової професійної майстерності сучасного працівника сфери освіти та їх вплив на розвиток особистості сучасного школяра.

Ключові слова: інформаційних та комунікаційних технологій, цифрової культури, новітні інноваційні інструменти навчання, учитель гірської школи, учні.

The author of the article highlights the current problem of the use of information and communication technologies in the educational sphere, in particular in mountain schools of the Ukrainian Carpathians. The level of development of the country is largely determined by the level of development of education, which at the present stage must quickly and qualitatively respond to the needs of society. One of the most important factors in reforming the education system in Ukraine is its informatization. The construction of effective systems of informatization of education, taking into account world experience, features and realities of the state of education, is the issue that deserves special attention in contemporary scientific theory and practice. The article explains the necessity of forming a digital culture and ICT competence as a separate component of the professional skills of the modern teacher and their influence on the development of the personality of the modern student.

Keywords: information and communication technologies, digital culture, innovative teaching tools, the teacher of the mountain school, students.

Автор статьи освещает актуальную проблему использования информационных и коммуникационных технологий в образовательной сфере, в частности в горных школах украинских Карпат. Уровень развития страны в значительной степени определяется уровнем развития образования, которое должно на современном этапе быстро и качественно реагировать на потребности общества. Одним из весомых факторов реформирования системы образования в Украине является информатизация. Построение эффективных систем информатизации образования с учетом мирового опыта, особенностей и реалий состояния отечественного образования - вопрос, который заслуживает особого внимания современной научной теории и практики. В статье объясняется необходимость формирования цифровой культуры и ИКТ-компетентности как отдельной составляющей профессионального мастерства современного педагога и их влияние на развитие личности школьника.

Ключевые слова: информационные и коммуникационные технологии, цифровая культура, новейшие инновационные инструменты обучения, учитель горной школы, ученики.

Постановка проблеми в загальному вигляді та її зв'язок з важливими науковими та практичними завданнями. Інформатизація усіх галузей суспільства й популярність інформаційних технологій у світі посіли чільне місце у житті й нашої країни і стали початком для нових змін у державі. Відкриваючи нові можливості для удосконалення усіх сфер життєдіяльності людини проблема розвитку та впровадження інформаційно- 
комунікаційних технологій (IKT) так і не знайшла належного відображення у перспективних планах соціальноекономічного розвитку регіонів. В Україні досі не розроблено покрокових завдань щодо підтримки, впровадження і використання IKT для підвищення рівня конкурентоспроможності країни на світовій арені.

У Концепції «Нова Школа» йдеться про те, що «наскрізне застосування інформаційно-комунікаційних технологій в освітньому процесі та управлінні закладами освіти і системою освіти має стати інструментом забезпечення успіху Нової школи. Запровадження IКT в освітній галузі має перейти від одноразових проектів у системний процес, який охоплює всі види діяльності. ІКТ суттєво розширять можливості педагога, оптимізують управлінські процеси, таким чином формуючи в учня важливі для нашого сторіччя технологічні компетентності» [6; с. 12].

Відповідно до «Глобального звіту про розвиток інформаційно-комунікаційних технологій - 2015» (The Global Information Technology Report), який, починаючи з 2002 року, щорічно видається Всесвітнім економічним форумом (World Economic Forum), Україна посіла 71 позицію серед 143 країн світу у рейтингу за рівнем розвитку інформаційно-комунікаційних технологій.

За основу рейтингової оцінки береться індекс мережевої готовності (Networked Readiness Index), що визначає рівень розкитку інформаційно-комунікаційних технологій у країнах світу. Серед країн ЄС - Швеція на 2 місці, Ісландія на 3-му, Польща на 37 місці. США перебувають на 17 місці індексу ІКТ. Лідером у цьому рейтингу вже котрий рік поспіль є Корея [5].

Нові цифрові технології несуть сьогодні крім широких можливостей також безліч економічних загроз. Втрата контролю над інформаційною економічною взаємодією й відсутність чіткої державної політики розвитку сфери IKT приводять до все більшої залежності від іноземної IT-продукції. Саме тому ретельне вивчення проблеми використання інформаційних та комунікаційних технологій в Україні та особливості їх застосування власне в освітній сфері повинно бути в центрі уваги сучасних вітчизняних та зарубіжних науковців.

Аналіз останніх досліджень і публікацій, у яких започатковано розв'язання проблеми. Україна, починаючи з 2000 р., активно займається формуванням інформаційного суспільства. Однак на цьому шляху постає чимало труднощів, пов'язаних насамперед з недостатнім технічним забезпеченням освітньої галузі, нерівномірністю функціонування телекомунікаційних послуг та обмеженістю доступу у сільській, гірській місцевості і депресивних регіонах, складним фінансовим забезпеченням цього процесу, неналежним законодавчим супроводом, а також відсутністю ґрунтовних наукових досліджень процесу формування інформаційного суспільства, цифрової грамотності освітян з урахуванням провідного зарубіжного досвіду.

Питанням аналізу й порівняння різних підходів до питання ІКТ-компетентності, її структурних компонентів займалися багато вітчизняних та зарубіжних науковців (В.А. Адольф, М.А. Горюнова, А.М. Семібратов, А.А. Єлізаров, М.Б. Лєбєдєва і О.Н. Шилова, М.А. Холодна). Їхні дослідження дають усі підстави стверджувати, що поняття ІКТкомпетентності є багатокомпонентним.

Формування мети статті. Метою статті $€$ дослідження проблеми формування та перспектив розвитку інформаційних і комунікаційних технологій в освітній галузі України, та зокрема у її гірських районах.

Виклад основного матеріалу дослідження з повним обґрунтуванням отриманих наукових результатів. Як було зазначено вище, за рівнем розвитку IT Україна посідає 71 місце у світі. Єдина конкурентно-спроможна перевага нашої держави в цьому аспекті, це традиційно сильні IT-кадри. 148 вищих навчальних закладів нашої країни здійснюють підготовку фахівців для IКT і демонструють високий рівень готовності програмістів. [5]. Однак очевидними є прогалини у підготовці фахівців освітньої галузі до впровадження та імплементації IKT та використання новітніх інноваційних інструментів для удосконалення навчально-виховного процесу у загальноосвітніх навчальних закладах. Якщо у міських школах тут ще проглядаємо якісь позитивні зрушення, то у школах гірських регіонів ситуація залишається бажати кращого.

Нині постає гостра необхідність IT - модернізації не лише сфери бізнесу, але освіти та медицини та ін. Практичний досвід свідчить про те, що рівень охоплення ІКТ вищою освітою дуже низький, рівень охоплення середньою та початковою освітою майже на нульовому рівні (Інтернет-доступ практично відсутній у більшості гірських шкіл - 67 позиція серед 143 країн світу), а рівень цифрової грамотності та культури дорослого населення країни ще нижчий. Сьогодні постає питання про формування цифрової культури педагога, оскільки інформаційні технології заполонили життя сучасної молоді, чому б не використати їх із користю у навчальновиховному процесі?

Цифрова культура педагога передбачає вміння працювати з сучасною цифровою технікою і володіти сучасними інформаційно-комунікаційними технологіями. Іншими словами вчитель сьогодення повинен мати так звану IKT-компетентність. До поняття цифрової культури фахівці відносять володіння вчителем такими ІКТ навичками, як комп'ютерна грамотність, інформаційна грамотність (інформаційна культура), мультимедійна грамотність та грамотність комп'ютерної комунікації [10].

Сьогодні постає питання необхідності щодо використання концепції компетентністного підходу в освіті, що є основою якісних змін у забезпеченні відповідності освіти запитам і можливостям суспільства періоду інформатизації і глобальної масової комунікації. Враховуючи принципи компетентністного підходу, суттю освіти стає розвиток здібностей, які сприятимуть самостійному вирішенню проблем в різних галузях і видах діяльності на основі використання соціального досвіду. У системі безперервної освіти компетентність є однією з основних характеристик результативності освіти в ланцюжку понять письменність - компетентність - культура - менталітет [8]. 
Виокремлення IКТ-компетентності як окремої складової професійної компетентності сучасного працівника сфери освіти обумовлено активним використання IKT у всіх сферах людської життєдіяльності.

У науковій літературі поняття IКТ-компетентності має різноманітне трактування. Так, П.В. Беспалов визначає дане поняття як інтегровану характеристику особистості, що передбачає мотивацію у засвоєнні відповідних знань, здатність вирішувати завдання у навчальній і професійній діяльності за допомогою комп'ютерної техніки і володіння прийомами комп'ютерного мислення. Ї̈̈ можна сформувати як на етапі вивчення комп'ютера, так і на етапі його використання як навчалього інструменту у професійній сфері. А.А. Єлізаров під ІКТ-компетентністю розуміє сукупність знань, умінь і досвіду діяльності, причому саме наявність такого досвіду, є визначальною відносно реалізації фахових функцій. О.М. Шилова та М.Б. Лєбєдєва визначають зазначувану компетентність як здатність індивіда вирішувати навчальні, життєві, професійні завдання за допомогою інформаційнокомунікаційних технологій [3].

За Н.В. Насировою, це - мотивація, потреба й інтерес до отримання знань, умінь і навичок у галузі технічних, програмних засобів й інформації. Компетентність педагогів в області ІКТ розглядається Л.М. Горбуновою і А.М. Семибратовим як готовність і здатність педагога самостійно і відповідально використовувати ці технології в своїй фаховій діяльності [3].

Вітчизняні науковці досліджували компетентності необхідні сучасному педагогу, а також розкрили зміст таких ключових компетентностей під час застосування інформаційних і комунікаційних технологій (М.І. Жалдак, Н.В. Морзе, О.В. Овчарук та ін.). Вони передбачають здатність орієнтуватися в інформаційному просторі, отримувати інформацію та оперувати нею відповідно до власних потреб і вимог сучасного високотехнологічного інформаційного суспільства [Там само].

Що ж має спонукати сучасного вчителя у гірській місцевості опанувати новітні інформаційні технології? На нашу думку це знайомство з досвідом вітчизняних та зарубіжних колег із питань використання IKT у своїй роботі, бажання оволодіти навичками роботи з комп'ютером, навчання на тренінгах з метою самовдосконалення, але найбільше - це власна мотивація зацікавити сучасних учнів до опанування шкільного предмету, можливість крокувати в нору зі світом.

Корисною для нас у цьому питанні є точка зору Сучкової Т.М. про те, що необхідно враховувати, що навчання чи підготовка учителя буде мало ефективною без систематичного використання технічних засобів на уроках [9]. На жаль, у деяких гірських школах мультимелійні дошки та проектори використовуються дуже рідко. То в чому ж причина?

Таким чином учителю доцільно продовжувати розвивати необхідні ІКТ-компетенції, долати обмежений погляд на комп'ютер лише як на технічний засіб навчання, призначений для демонстрації окремих слайдів, текстів і готових програм, а переходити на якісно інший рівень володіння ІКТ-компетентностями. Педагог, використовуючи власні вміння користувача, починає застосовувати набуті знання для оволодіння навичками використання апаратних засобів ПК і мультимедійного обладнання, для опанування можливостями послуг Інтернет мережі, для формування навичок користування спеціальними програмами (архіватори, тощо) і програмним забезпеченням навчального призначення з метою підтримки навчання шкільних предметів, а пізніше й для самостійного створення власних дидактичних мультимедійних матеріалів та освітніх електронних ресурсів з метою підтримки навчання цих предметів, підготовки та проведення позакласних заходів тощо. Він поступово стає ІКТ-активним учителем.

Далі наступний крок - практичний (фаховий) рівень володіння ІКТ-компетентностями. Свідченням цього $€$ навички роботи вчителя з мультимедійним обладнанням, використання різноманітних навчальних ігор пізнавального призначення і ресурсів мережі Інтернет у професійній діяльності, розробка свого авторського методичного супроводу і застосування програмного забезпечення в навчально-виховному процесі. Учитель не повинен забувати працювати над подальшим саморозвитком своїх IКТ-компетентностей шляхом навчання на дистанційних курсах, підвищенням цифрової культури та обміном досвідом через участь у мережевих педагогічних спільнотах, форумах, семінарах, тренінгах, круглих столах та освітніх проектах. Сьогодні для цього $€$ безліч можливостей.

ІКТ-активний та креативний учитель має усі шанси стати повноправним членом єдиного освітнього інформаційного середовища. Він повинен працювати над узагальненням та поширенням педагогічному колу власного досвіду, займатися рекламою свого навчального закладу й ділитися його досягненнями, розробляти і розповсюджувати авторські методичні посібники з проблем використання IКT під час навчання свого предмету в мережі Інтернет, брати участь у наукових дискусіїх, тощо.

Висновки і перспективи подальших досліджень. IКТ-компетентність заслуговує на особливу увагу тому, що саме вона дає можливість сучасному вчителеві бути активним у освітньому інформаційному середовищі, використовувати найновітніші досягнення науки й техніки в своїй фаховій діяльності. Важливість формування ІКТграмотності мешканців гірських регіонів, створення безперервної системи підвищення кваліфікації в галузі ІКТ чітко відображена в Міжнародній програмі ЮНЕСКО «Інформація для всіх». Саме з цією метою в Україні восини 2017 р. стартував проект програми ЄС ЕРАЗМУС + КА2 з розвитку потенціалу вищої освіти: «Модернізація педагогічної вищої освіти з використанням інноваційних інструментів викладання» (MoPED) - № 586098-EPP-1UA-EPPKA2-CBHE-JP. Цей проект, переконані експерти, позитивно вплине на якість вищої педагогічної освіти та покращить цифрові та дидактичні компетенції майбутніх учителів шкіл, зокрема й гірських. 
Формування IКТ-компетентності безумовно сприяє всебічному розвитку педагогів; їх самовдосконаленню; бажанню вчитися впродовж усього життя; розумінню інформаційно-комунікаційних процесів; здатності застосовувати опановане у професійній діяльності; удосконалювати фахову майстерність; використовувати набуті знання у педагогічній практиці, що забезпечує значне підвищення якості освіти у гірському серидовищі.

Інформація та знання - найважливіший ресурс, товар і продукт сучасного суспільства. Формування інформаційних ресурсів та їх системне використання стають об'єктом політичних і економічних інтересів як на національному, так і на міжнародному рівнях. Світова економіка переходить на новий рівень свого розвитку, де IKT € одним із основних засобів виробництва. Наразі, не кожен український педагог може похизуватися високим рівнем розвитку IКТ компетентності, але існують серйозні задатки та перспективи, щоб розвивати та удосконалювати дану галузь, впроваджувати новітні технології у навчальний процес, що безумовно піде на користь не лише учням гірських шкіл нашої держави, а й усій освітній спільноті загалом.

1. Антонюк В. Комп'ютерна грамотність як складова професійної компетентності сучасного педагога. [Електронний ресурс] / - Режим доступу: https://www.google.com.ua/url?sa=t\&rct=j\&q=\&esrc=s\&source=web\&cd=15\&cad=rja\&uact=8\&ved=0CEc QFjAEOAo\&url=http\%3A\%2F\%2Fdspace.tnpu.edu.ua\%2Fbitstream\%2F123456789\%2F957\%2F1\%2FAntonyk.pdf\&ei=oxgaU4zG GcfX4ATvqIG4AQ\&usg=AFQjCNFSYSK2wSi1FsbazKKOgDHUJOzb7w\&sig2=k9K1tRXezF4-H5ECsq6bdQ

2. Биков, В. Ю. Сучасні завдання інформатизації освіти / В.Ю. Биков. // Інформаційні технології і засоби навчання: електронне наукове фахове видання [Електронний ресурс] / Ін-т інформ. технологій і засобів навчання АПН України, Ун-т менеджменту освіти АПН України; гол. ред.: В.Ю. Биков. - 2010. - № 1(15). - Режим доступу: http://www.ime.edu-ua.net/em15/ emg.html

3. ІКТ-компетентність вчителів. [Електронний ресурс] / - Режим доступу: http://uk.compu.wikia.com/wiki/ ІКТ-компетентність_вчителів

4. Інформаційна культура. [Електронний ресурс] / - Режим доступу: http://uk.wikipedia.org/wiki/Інформаційна_культура

5. Михайловська, О. В. Місце України у світовому процесі розбудови інформаційного суспільства [Текст] /О. В. Михайловська. - Актуальні проблеми економіки. - №12((102)). - 2009. - С. 36-44.

6. Нова школа - Міністерство освіти і науки України. - Режим доступу: mon.gov.ua/Новини\%202016/08/21/2016-08-17-3-.pdf

7. Проект Програми розвитку сфери інформаційно-комунікаційних технологій в Україні / Держінформнауки, липень 2013.

8. Папернова, Т. В. Формування Ікт-компетентності педагога в системі неперервної освіти. - Режим доступу: http://www. sworld.com.ua/index.php/ru/ pedagogy-psychology-and-sociology-311/interactive-learning-technologies-and-innovations-ineducation-311/7417-formuvannya-ktkompetentnost-teacher

9. Сучкова, Т. М. Оценка ИКТ-компетентности учителя [Електронний ресурс] / Т.М. Сучкова. - Режим доступу: http:// pedsovet.org/component/option, com_mtree/task,viewlink/link_id,6072/Itemid,118/

10. Цифрова культура педагога. [Електронний ресурс] / -. Режим доступу: http://dn.hoippo.km.ua/wiki/index.php/ Цифрова_культура/

\section{Reference}

1. Antonyuk V. Komp'yuterna hramotnist' yak skladova profesiynoyi kompetentnosti suchasnoho pedahoha. [Elektronnyy resurs] / - Rezhym dostupu: https://www.google.com.ua/url?sa=t\&rct=j\&q=\&esrc=s\&source=web\&cd=15\&cad=rja\&uact=8\&ved=0CE cQFjAEOAo\&url=http\%3A\%2F\%2Fdspace.tnpu.edu.ua\%2Fbitstream\%2F123456789\%2F957\%2F1\%2FAntonyk.pdf\&ei=oxgaU4zG GcfX4ATvqIG4AQ\&usg=AFQjCNFSYSK2wSi1FsbazKKOgDHUJOzb7w\&sig2=k9K1tRXezF4-H5ECsq6bdQ

2. Bykov, V. YU. Suchasni zavdannya informatyzatsiyi osvity / V.YU. Bykov. // Informatsiyni tekhnolohiyi i zasoby navchannya: elektronne naukove fakhove vydannya [Elektronnyy resurs] / In-t inform. tekhnolohiy i zasobiv navchannya APN Ukrayiny, Un-t menedzhmentu osvity APN Ukrayiny; hol. red.: V.YU. Bykov. - 2010. - № 1(15). - Rezhym dostupu: http://www.ime.edu-ua.net/ em15/emg.html

3. IKT-kompetentnist' vchyteliv. [Elektronnyy resurs] / - Rezhym dostupu: http://uk.compu.wikia.com/wiki/ IKT-kompetentnist_vchyteliv

4. Informatsiyna kul'tura. [Elektronnyy resurs] / - Rezhym dostupu: http://uk.wikipedia.org/wiki/Informatsiyna_kul'tura

5. Mykhaylovs'ka, O. V. Mistse Ukrayiny u svitovomu protsesi rozbudovy informatsiynoho suspil'stva [Tekst] /O. V. Mykhaylovs'ka. Aktual'ni problemy ekonomiky. - №12((102)). - 2009. - S. 36-44.

6. Nova shkola - Ministerstvo osvity i nauky Ukrayiny. - Rezhym dostupu: mon.gov.ua/Novyny\%202016/08/21/2016-08-17-3-.pdf

7. Proekt Prohramy rozvytku sfery informatsiyno-komunikatsiynykh tekhnolohiy v Ukrayini / Derzhinformnauky, lypen' 2013.

8. Papernova, T. V. Formuvannya Ikt-kompetentnosti pedahoha v systemi neperervnoyi osvity. - Rezhym dostupu: http://www. sworld.com.ua/index.php/ru/ pedagogy-psychology-and-sociology-311/interactive-learning-technologies-and-innovations-ineducation-311/7417-formuvannya-ktkompetentnost-teacher

9. Suchkova, T. N. Otsenka IKT-kompetentnosti uchitelya [Elektronnyy resurs] / T.M. Suchkova. - Rezhim dostupa: http://pedsovet. org/component/option, com_mtree / task, viewlink / link_id, 6072 / Itemid, 118 /

10. Tsyfrova ku'tura pedahoha. [Elektronnyy resurs] / - . Rezhym dostupu: http://dn.hoippo.km.ua/wiki/index.php/Tsyfrova_kul'tura/
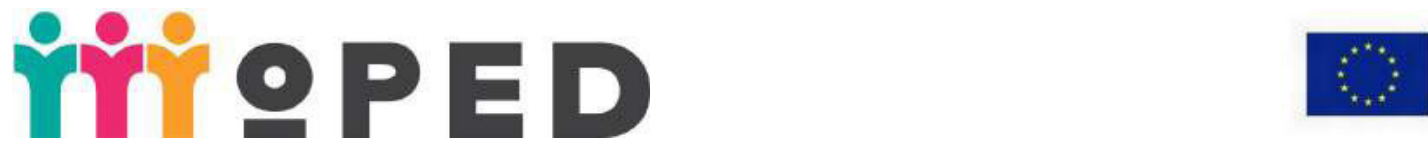

Co-funded by the Erasmus+ Programme of the European Union

"The article has been prepared in the framework of the Erasmus+ project "MoPED - Modernization of Pedagogical Higher Education by Innovative Teaching Instruments", No. 586098-EPP-1-2017-1-UA-EPPKA2-CBHE-JP. This project has been funded with support from the European Commission. This publication reflects the views only of the author, and the Commission cannot be held responsible for any use which may be made of the information contained therein». 